\title{
Rhizoctonia solani AG-1 IA infects both rice and signalgrass in the Colombian Llanos ${ }^{1}$
}

\author{
Lina Maria Ramos-Molina ${ }^{2}$, Edisson Chavarro-Mesa², \\ Danilo Augusto dos Santos Pereira ${ }^{3}$, María del Rosario Silva-Herrera ${ }^{4}$, Paulo Cezar Ceresini ${ }^{3}$
}

\section{ABSTRACT}

Foliar blight and death of signalgrass (Urochloa spp.) pastures are caused by the Rhizoctonia solani fungus. This study aimed at determining which pathogens from the Rhizoctonia species complex are associated with leaf and sheath blight in Urochloa and rice, in the Colombian Llanos. Sympatric areas of Urochloa pastures adjacent to rice cropping areas were sampled using a linear transect system. The pathogens were identified using morphological traits, molecular detection based on specific primers and sequencing of the ITS-5.8S rDNA region. $R$. solani AG-1 IA predominated as the pathogen associated with foliar blight in all samples from U. brizantha cv. 'Toledo' and hybrid Urochloa cv. 'Mulato'. Besides $R$. solani AG-1 IA (18\% of the samples), Rhizoctonia oryzae-sativae (71\%) and Sclerotium hydrophilum (11\%) were also detected. In the cross-pathogenicity test, the $R$. solani AG-1 IA fungus was the most aggressive to Urochloa, while $R$. oryzae-sativae produced very mild infection symptoms. This is the first report of $R$. oryzae-sativae and $S$. hydrophilum associated with the complex of rice sheath blight diseases in Colombia.

KEY-WORDS: Urochloa spp.; Rhizoctonia oryzae-sativae; Sclerotium hydrophilum.

\section{INTRODUCTION}

Signalgrass (Urochloa spp.) foliar blight and collar rot diseases are caused by the Basidiomycetes Rhizoctonia solani (sexual stage Thanatephorus cucumeris) fungus, which emerged early in 1990 as an important pathogen for Urochloa pastures in the eastern Colombian Llanos (Ciat 1993, Argel et al. 2005, Alvarez et al. 2013). The emergence of these diseases was first reported in areas previously occupied by rice, a highly susceptible host (Lee \&

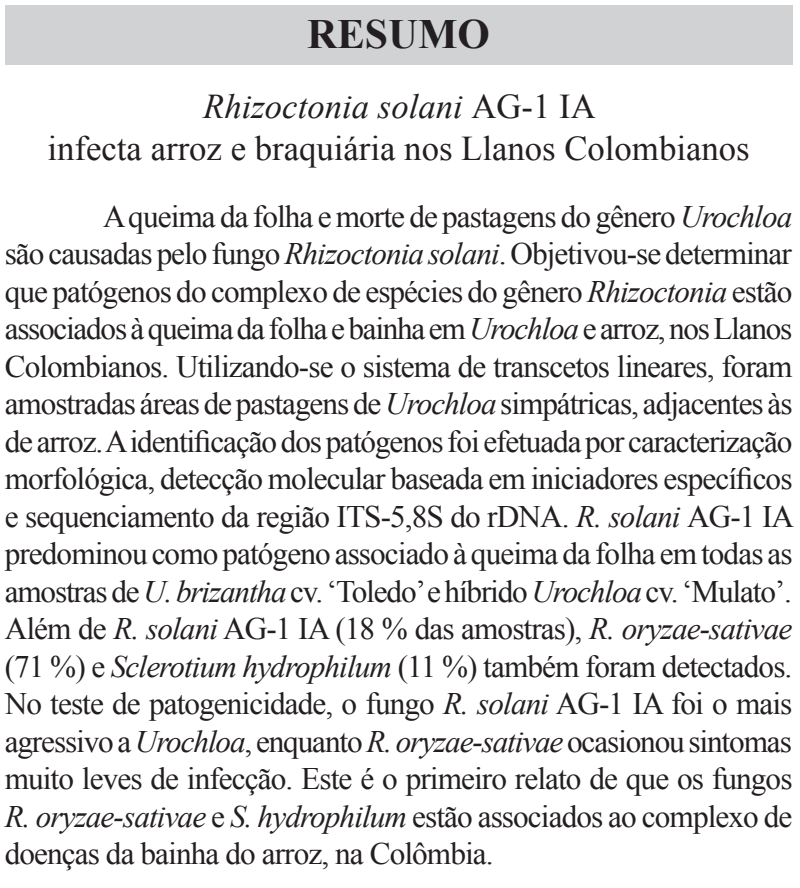

PALAVRAS-CHAVE: Urochloa spp.; Rhizoctonia oryzaesativae; Sclerotium hydrophilum.

Rush 1983). In the same Colombian region, roughly two decades ago, the occurrence of sheath blight caused by $R$. solani AG-1 IA in rice was also observed for the first time (Pabón Guerrero 1994). R. solani is a complex species composed of various anastomosis groups (AGs) with high host specificity (Adams 1988, Sneh et al. 1996).

Although no precise data are available regarding economic losses caused by foliar blight and death of Urochloa, the disease is considered severe (Argel et al. 2005, Duarte et al. 2007, Alvarez

1. Manuscript received in Nov./2015 and accepted for publication in Mar./2016 (http://dx.doi.org/10.1590/1983-40632016v4638696).

2. Universidade Estadual Paulista, Departamento de Fitossanidade, Engenharia Rural e Solos, Ilha Solteira, SP, Brazil.

E-mails: limaramo@gmail.com, bioedicha@gmail.com,paulo.ceresini@bio.feis.unesp.br.

3. ETH Zurich, Institute of Integrative Biology - Plant Pathology, Zurich, Switzerland. E-mail: danilo455@gmail.com.

4. Universidad de los Llanos, Villavicencio, Meta, Colombia.E-mail: rosariosilvasa@yahoo.com. 
et al. 2013). The estimate of losses in rice production caused by sheath blight can reach up to $50 \%$ (Savary et al. 2000).

In the south of the United States, Urochloa spp. was reported as host for two distinct AGs of the $R$. solani species complex: AG-1 IA and AG-1 IB (Black et al. 1996). A recent description from 2013 indicated a prevalence of $R$. solani AG-1 IA infecting pastures of Urochloa ( $69 \%$ of total samples) in the warm regions of Colombia: Casane and Córdoba. On the other hand, Rhizoctonia sp. AG-D (Ceratobasidium sp.) was more commonly found in regions with lower temperatures such as Cauca ( $31 \%$ of the samples) (Alvarez et al. 2013).

It is possible that different pathogens from the Rhizoctonia complex could be associated with foliar blight and death of Urochloa in the Colombian Llanos, especially in areas close to rice fields.

Besides R. solani AG-1 IA, in South America, the species $R$. circinata var. oryzae, $R$. circinata var. zeae, $R$. circinata var. circinata (sexual stage Waitea circinata), $R$. oryzae-sativae (sexual stage Ceratobasidium oryzae-sativae) and even Sclerotium (S. hydrophilum and S. oryzae) have already been described as being associated with the rice sheath blight complex (Cedeño et al. 1996, Madariaga et al. 1999, Gutiérrez 2007).

The management of Urochloa foliar blight and collar rot and rice sheath blight complexes relies heavily on varietal resistance (Nunes et al. 2004). Therefore, it is important to understand the relative importance of each Rhizoctonia species/groups, in order to improve disease management.

This study aimed at determining which pathogens from the Rhizoctonia species complex are associated with foliar and sheath blight in Urochloa spp. and rice, in the Colombian Llanos.

\section{MATERIAL AND METHODS}

Population samples of infected Urochloa and rice were collected between 2010 and 2011, in the Meta State, eastern Colombian Llanos, in Colombia (Figure 1). Samples were collected in Puerto López, from Urochloa brizantha cv. 'Toledo' (BBT1) and hybrid Urochloa cv. 'Mulato' (BHM3) with foliar blight symptoms, and in adjacent areas from 'Fedearroz 50' (OS5) rice plants with sheath blight or spot symptoms (Figure 1, Table 1).
The transect sampling system, with six lines in each cropping area and seven to eight sampling points per line, was used. Employing the same system, the following hosts with disease symptoms were sampled in the Villavicencio county: U. brizantha cv. 'Toledo' (BBT2), hybrid Urochloa cv. 'Mulato' (BHM4) and rice cv. 'Thailandia' (OS6) (Figure 1, Table 1). Isolations were initially performed by disinfecting leaf fragments in sodium hypochlorite $1 \%$, followed by transference to PDA media (potato-dextrose-agar,

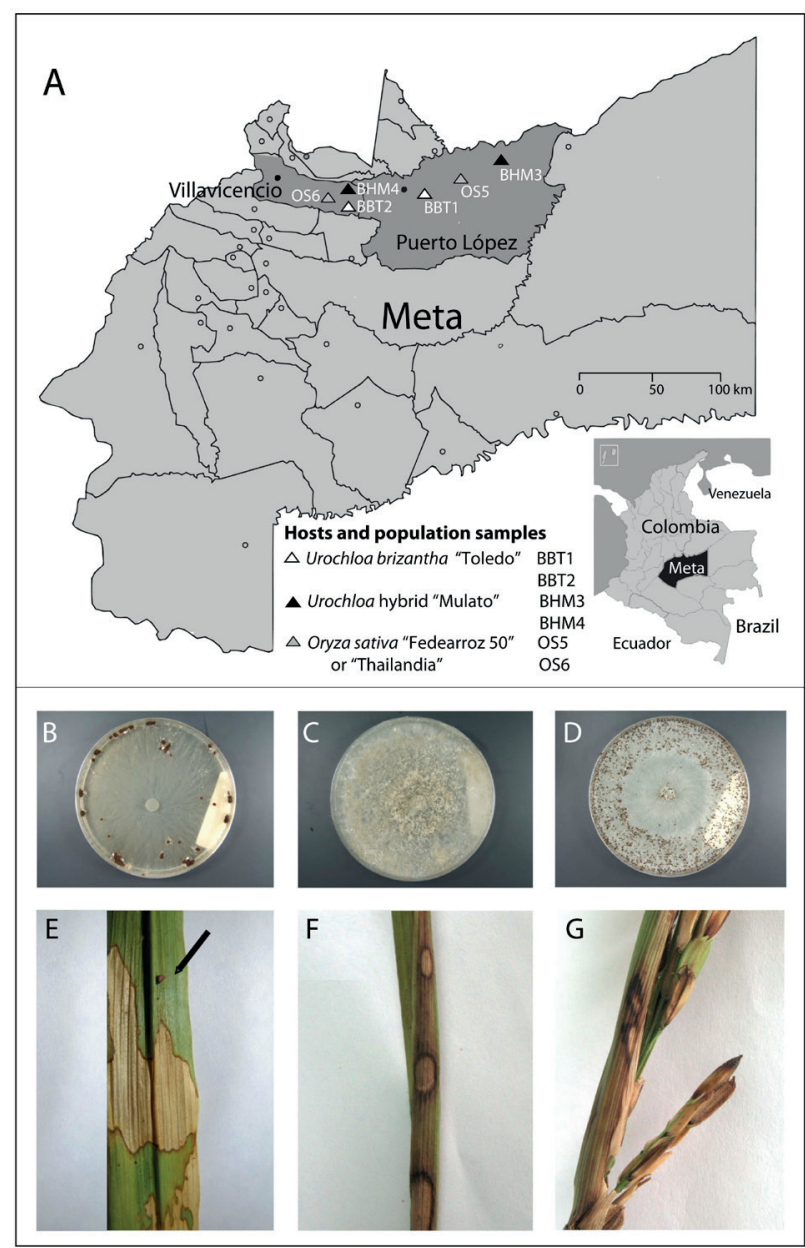

Figure 1. Geographic locations of Urochloa spp. and rice sampled in Colombia, morphological differences among fungi and the disease symptoms of foliar blight and sheath spot or blight. (A) Geographic location of sampled areas close to Puerto López and Villavicencio, in Meta; (B) sasakii-type sclerotia of Rhizoctonia solani AG-1 IA; (C) sclerotia of $R$. oryzae-sativae; (D) sclerotia of Sclerotium hydrophilum; (E) foliar blight symptoms in Urochloa brizantha cv. 'Toledo' related to $R$. solani AG-1 IA; (F and G) symptoms of rice sheath spot related to $R$. oryzae-sativae and Sclerotium hydrophilum. 
Table 1. Populations of Urochloa spp. and rice associated with foliar fungi pathogens.

\begin{tabular}{|c|c|c|c|c|c|c|c|}
\hline \multirow[b]{2}{*}{ District } & \multirow[b]{2}{*}{ Host } & \multirow[b]{2}{*}{ Cultivar } & \multirow[b]{2}{*}{ Population } & \multirow[b]{2}{*}{$\begin{array}{c}\text { Sample } \\
\text { size }(\mathrm{N})^{\mathrm{a}}\end{array}$} & \multicolumn{3}{|c|}{ Total isolate number ${ }^{b}$} \\
\hline & & & & & $\begin{array}{c}\text { Rhizoctonia } \\
\text { solani AG-1 IA }\end{array}$ & $\begin{array}{l}\text { R. oryzae- } \\
\text { sativae }\end{array}$ & $\begin{array}{c}\text { Sclerotium } \\
\text { hydrophilum }\end{array}$ \\
\hline \multirow[t]{3}{*}{ Puerto López } & U. brizantha & 'Toledo' & BBT1 & 38 & 38 & - & - \\
\hline & Urochloa & Hybrid 'Mulato' & BHM3 & 40 & 40 & - & - \\
\hline & Rice & 'Fedearroz 50' & OS5 & 38 & 2 & 36 & - \\
\hline \multirow[t]{3}{*}{ Villavicencio } & U. brizantha & 'Toledo' & BBT2 & 42 & 42 & - & - \\
\hline & Urochloa & Hybrid 'Mulato' & BHM4 & 41 & 41 & - & - \\
\hline & Rice & 'Thailandia' & Os6 & 35 & 11 & 16 & 8 \\
\hline Total & & & & 234 & 174 & 52 & 8 \\
\hline
\end{tabular}

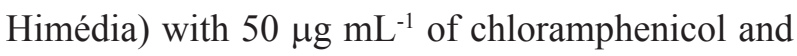
streptomycin. Plates were kept at $25^{\circ} \mathrm{C}$ in the dark for up to $48 \mathrm{~h}$. Pure cultures were isolated after transference of typical Rhizoctonia-like mycelia to new PDA plates.

For DNA extraction, fungal mycelium was grown in $30 \mathrm{~mL}$ of potato dextrose broth $\left(18.5 \mathrm{~g} \mathrm{~L}^{-1}\right)$, for 5 days, on a shaker at $75 \mathrm{rpm}$, after which the mycelium was collected by filtration and freeze-dried for approximately $48 \mathrm{~h}$. DNA was extracted using a GenElute kit (Sigma-Aldrich), according to the manufacturer's instructions.

Isolates were identified based upon mycelia and sclerotia morphological characteristics (Sneh et al. 1996, Yang et al. 1989, Costa-Souza et al. 2007, Gutiérrez 2007, Lanoiselet et al. 2007 ) and via polymerase chain reaction (PCR), using primers for the ribosomal DNA regions 28S and ITS-5.8S (Johanson et al. 1998, Matsumoto 2002). Selective amplification of the 28S rDNA was performed for all isolates using RS-CMF/AG-1AR primer pairs specific to $R$. solani AG1-IA (Matsumoto 2002). For rice isolates, primers GMROS-6/R635 for the ITS-5.8S rDNA, specific to $R$. oryzae-sativae, were used (Johanson et al. 1998). PCR conditions were the same as described previously (Johanson et al. 1998, Matsumoto 2002).

The ribosomal DNA ITS-5.8S of 64 sampled fungi was sequenced using the primers ITS4 and ITS5 (Johanson et al. 1998, Matsumoto 2002). PCR product sequence was performed by Macrogen (South Korea). Sequence data from both ends of each amplicon (one forward and one reverse per isolate) were assembled, aligned and concatenated using Chromas (Technelysium, Australia). Phylogenetic analyses were performed through neighbor-joining (NJ) inference and the Kimura model for genetic distance using MEGA v.5.0 (Tamura et al. 2011). The statistical support for each clade in the obtained tree was tested using bootstrap resampling with 1,500 permutations.

For the cross-pathogenicity study, $24 R$. solani AG-1 IA isolates were selected, 12 from Urochloa spp. and 12 from rice. Nine $R$. oryzae-sativae isolates and seven $S$. hydrophilum isolates from rice were also included, totaling 40 isolates. The rice cultivar 'Fedearroz' and U. brizantha cv. 'Toledo' were used as hosts, and uninoculated control plants were included in the assay. Seeds were surface-sterilized with $1 \%$ sodium hypochlorite for $20 \mathrm{~min}$ prior to sowing. Four seeds were sown in each pot filled with a soil and sand mix (2:1). After seedling emergence, the pots were thinned to one seedling per pot. Plants were fertilized with $1 \mathrm{~g}$ of NPK (15:15:15) granular fertilizer. The pots were watered daily and kept in a greenhouse under natural conditions until inoculation.

Inoculation with $R$. solani sclerotia, $R$. oryzaesativae or $S$. hydrophilum mycelium plug $(6 \mathrm{~mm})$ was performed when the plants had four leaves. The inoculum was applied to the base of the last or second-to-last leaf of the main tiller and attached with parafilm. The infected plants were kept in a phytotron in high humidity (95\%), with daytime temperatures maintained between $25^{\circ} \mathrm{C}$ and $27^{\circ} \mathrm{C}$. Evaluation was performed 6 days after inoculation of rice and 12 days after inoculation of Urochloa by measuring the maximum tiller length and the lesion length on the tiller. A disease index was calculated according to the following equation: $9 \mathrm{x}$ (length of the lesion on the tiller/maximum tiller length) (Jia et al. 2007). The rating of the experimental unit was the combined scores from up to four tillers. To detect evidence of host specialization, analysis of variance followed by a 
priori contrast analysis between groups of isolates was performed using SAS 9.1 (SAS System for Windows, SAS Institute, Cary, NC). The statistical analyses were performed independently for each experiment, being completely randomized, with three replications each.

\section{RESULTS AND DISCUSSION}

The 234 isolates obtained are described in Table 1. Based on cultural and morphological characteristics, isolates from six plant populations with visual symptoms of foliar blight and death of Urochloa and rice sheath spot and blight were classified in three distinct groups (Table 1). Isolates in the first group showed sasakii-type sclerotia on light brown-colored cultures (Figure 1B), similar to R. solani AG-1 IA(Sneh et al. 1996, Yang et al. 1989). This group contains 161 isolates from Urochloa spp. and 13 from rice plants.

A similar report was made by Alvarez et al. (2013), who found that $R$. solani AG-1 IA was the predominant pathogen associated with foliar blight in U. brizantha, U. brizantha cv. 'Toledo', U. decumbens, U. mutica, Urochloa cv. 'Mulato' and 'Mulato II', in Colombia. The second group includes 52 isolates obtained only from rice, with small and irregular-shaped sclerotia and with light brown mycelium (Figure 1C), similar to R. oryzae-sativae (Lanoiselet et al. 2007). The last group consists of eight isolates obtained from rice, showing small round sclerotia with a dark brown to black color (Figure 1D), like S. hydrophilum (Gutiérrez 2007).

The 161 fungi isolates obtained from symptomatic Urochloa app. and 13 isolates obtained from sheath lesions in rice resulted in positive amplification with primers specific to $R$. solani AG-1 IA. Another 52 isolates from rice plants were positively amplified with primers specific to $R$. oryzae-sativae, and the remaining eight isolates from the third group did not exhibit amplification for any of the Rhizoctonia specific molecular primers used.

Phylogenetic inferences were based on rDNA ITS sequences of isolates from the three groups (Figure 2). From the first group, 55 isolates (represented by 9 distinct haplotypes in the superior phylogenetic tree) had similar sequences to $R$. solani AG-1 IA sequences. These isolates are composed of individuals from the populations BBT1 and BBT2 (15 isolates), BHM3 and BHM4 (29 isolates), and
OS5 and OS6 (11 isolates). The second biggest group, whose sequences were similar to $R$. oryzae-sativae, was composed of four isolates from the OS5 and OS6 populations. Finally, a third group of five isolates from the OS5 and OS6 populations showed similar sequences to $S$. hydrophilum. The phylogenetic inference corroborates the initial identification performed by morphologic characteristics and specific PCR detection.

This is the first report of $R$. oryzae-sativae and $S$. hydrophilum associated with the sheath blight

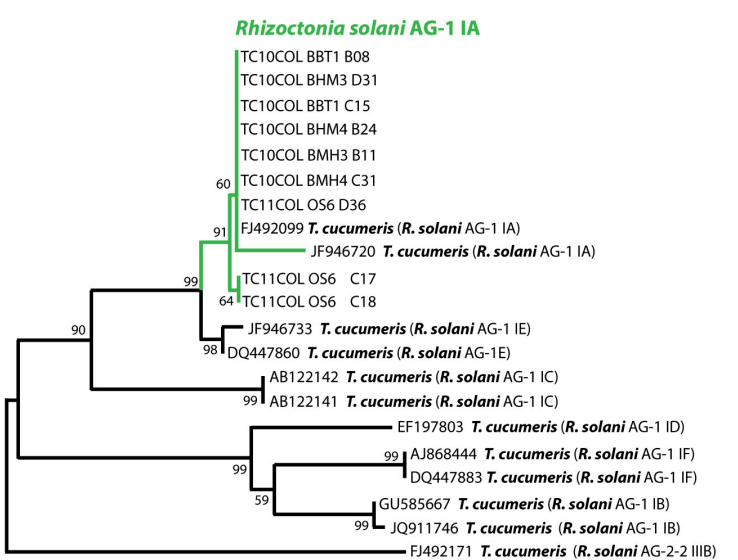

0.01
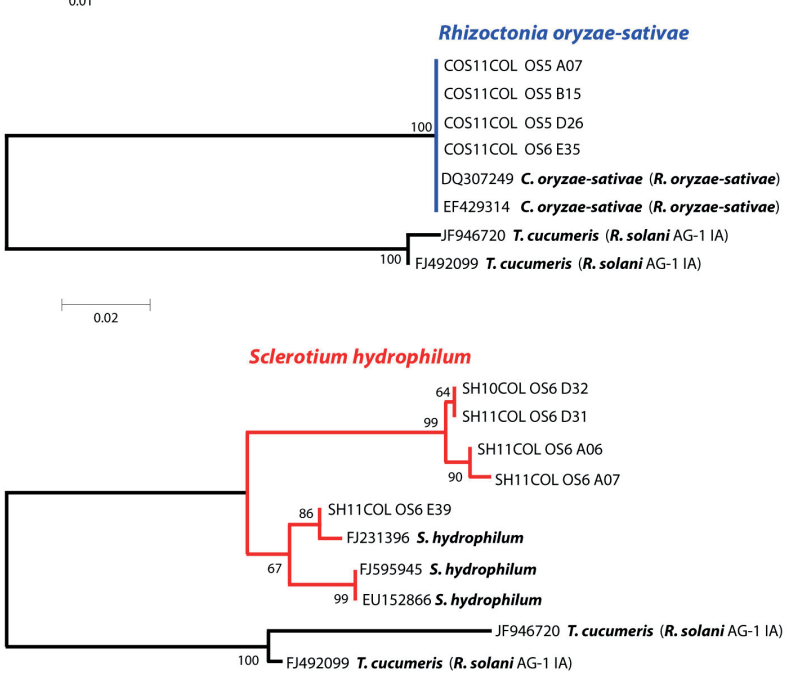

0.02

Figure 2. Phylogenetic trees, based on neighbor-joining distance, illustrating the relation among ITS-5.8S haplotypes of Rhizoctonia solani AG-1 IA, R. oryzae-sativae and Sclerotium hydrophilum. The bars indicate genetic distance among clades. Supporting values of bootstrap above $50 \%$ are by each branch. The bold case names are sequences downloaded from NCBI/Genbank, to serve as control, of known species and anastomosis group, to aid classification. 
and spot disease complexes of rice in Colombia. The predominance of $R$. oryzae-sativae in the two rice sampling areas in the Colombian Llanos (71\% of the population sampling) is particularly important for disease management, since $R$. solani AG-1 IA was considered the predominant pathogen in rice fields (Pabón Guerrero 1994). In South and North America, several species of the Rhizoctonia genus, such as $R$. solani AG-1 IA, $R$. circinata var. oryzae, $R$. circinata var. zeae, $R$. circinata var. circinata, $R$. oryzae-sativae and Sclerotium (S. hydrophilum and $S$. oryzae), are associated with the rice sheath blight and spot disease complexes in Argentina (Gutiérrez 2007), Brazil (Costa-Souza et al. 2007), Chile (Madariaga et al. 1999), USA (Lee \& Rush 1983, Sayler \& Yang 2007) and Venezuela (Cedeño et al. 1996).

Specifically, $R$. solani AG-1 IA is associated with sheath blight, $R$. circinata var. oryzae with sheath spot, $R$. oryzae-sativae with aggregated sheath spot, $S$. hydrophilum with sheath spot and $S$. oryzae with sheath rot (Gutiérrez 2007). The overlapping of similar symptoms reduces assertive diagnosis for these rice sheath diseases (Cedeño et al. 1996, Johanson et al. 1998). As diagnosis is a highly relevant step for establishing proper management strategies, especially with varietal resistance, simple methods are recommended, such as morphological characterization, to identify the associated pathogens.

The cross-pathogenicity assay in rice (cv. 'Fedearroz') showed that $R$. oryzae-sativae and $S$. hydrophilum are capable of inducing symptoms, however, with lower intensity than $R$. solani AG-1 IA isolates (Figure 3). On the other hand, R. oryzaesativae and $S$. hydrophilum isolates practically do not induce symptoms in $U$. brizantha (cv. 'Toledo') (Figure 3).

R. solani AG-1 IA isolates obtained from Urochloa spp. populations were more aggressive to $U$. brizantha (cv. 'Toledo') than isolates obtained from rice (Figure 3). In rice, however, isolates from Urochloa spp. were similarly aggressive, when compared to rice isolates of $R$. solani AG-1 IA.

These findings support the hypothesis that R. solani AG-1 IA isolates infecting Urochloa spp. most likely originated from a population that originally infected rice via host shift (Chavarro Mesa et al. 2015). Similar examples are known to have occurred, such as host jump (from rice to soybean) or host shift (from rice to maize) of $R$. solani AG-1

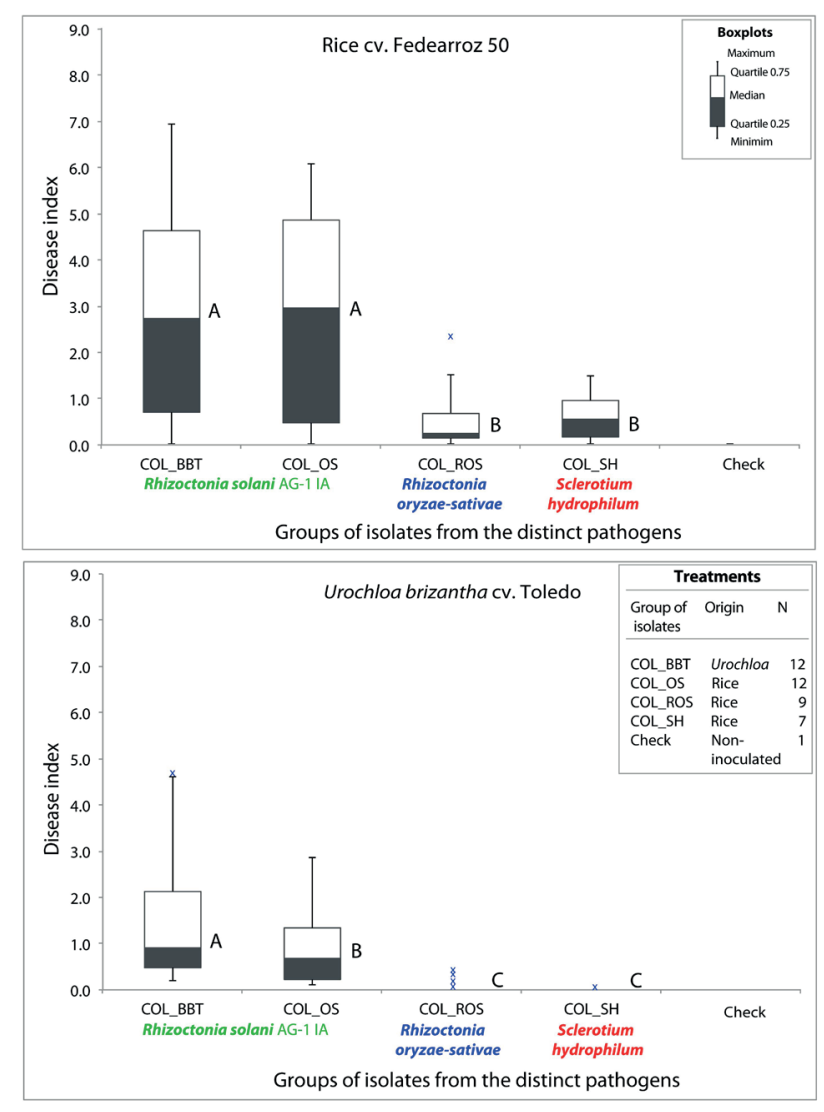

Figure 3. Aggressiveness of Rhizoctonia solani AG-1 IA, R. oryzae-sativae and Sclerotium hydrophilum groups of isolates from the Colombian Llanos to Urochloa and rice. Means followed by the same letter are not significantly different by contrast of means $(p \leq 0.01)$.

IA populations in the southern United States (Assis et al. 2008) and Venezuela (González-Vera et al. 2010).

A recent study indicated that $R$. solani AG-1 IA isolates from Urochloa (syn. Brachiaria) were also pathogenic to cowpea and soybean (Chavarro Mesa et al. 2015). These results provide evidence that the R. solani AG-1 IA populations adapted to Urochloa spp. most likely are not genetically structured, and therefore keep a wide host range, extending also to the Fabaceae family.

\section{CONCLUSIONS}

1. Rhizoctonia solani AG-1 IA is the predominant pathogen associated with foliar blight in U. brizantha cv. 'Toledo' and hybrid Urochloa cv. 'Mulato', in the eastern Colombian Llanos.

2. Urochloa infecting R. solani AG-1 IA showed the highest disease intensity in Urochloa spp. 
3. Isolates of R. solani AG-1 IA from rice or Urochloa are cross pathogenic in both plant species.

4. $R$. oryzae-sativae and $S$. hydrophilum were detected only in rice, but $R$. oryzae-sativae could produce very light symptoms in Urochloa.

\section{ACKNOWLEDGMENTS}

This study was funded by Fundação de Amparo à Pesquisa do Estado de São Paulo (FAPESP) - Biota research grant to P. C. Ceresini (2011/50150-3), research fellowship (Pq-2 307361/2012-8) and grant (485244/2012-8) from Conselho Nacional de Desenvolvimento Científico e Tecnológico (CNPq) to P. C. Ceresini. L. M. Ramos Molina was supported by a PhD studentship from $\mathrm{CNPq}$ - DR (140564/2009-8), E. Chavarro Mesa by a PhD studentship from FAPESP (2011/23050-8) and D. A. S. Pereira by a MSc studentship from FAPESP (2013/11944-0). We thank A. Y. Perez Barragan (CNPq-AT 376421/2012-6), I. Lopez Garcia (CNPq-IC 117888/2013-3), M. M. Negrisoli (CNPq-IC 163835/2012-8), S. N. Campos (CNPq-AT 370186/2015-0) and M. Zala (ETH Zurich) for their technical assistance on this research.

\section{REFERENCES}

ADAMS, G. C. Thanathephorus cucumeris (Rhizoctonia solani), a species complex of wide host range. In: INGRAM, D. S.; WILLIAMS, P. H. (Eds.). Genetics of plant pathogenic fungi. London: Academic Press, 1988. p. 535-552.

ALVAREZ, E. et al. Diversity of Rhizoctonia spp. causing foliar blight on Brachiaria in Colombia and evaluation of Brachiaria genotypes for foliar blight resistance. Plant Disease, Saint Paul, v. 97, n. 6, p. 772-779, 2013.

ARGEL, P. J. et al. Cultivar Mulato (Brachiaria híbrido CIAT 36061): gramínea de alta producción y calidad forrajera para los trópicos. Palmira: CIAT, 2005.

ASSIS, J. B. de et al. Divergence between sympatric riceand soybean-infecting populations of Rhizoctonia solani anastomosis group-1 IA. Phytopathology, Saint Paul, v. 98, n. 12, p. 1326-1333, 2008.

BLACK, B. D. et al. Weed hosts for Rhizoctonia solani, causal agent for rhizoctonia foliar blight of soybean (Glycine max). Weed Technology, Lawrence, v. 10, n. 4, p. 865-869, 1996.

CEDEÑO, L. et al. Rhizoctonia solani AG-1-IA, causa principal del añublo de la vaina del arroz en Venezuela. Fitopatologia Venezolana, Maracay, v. 9, n. 1, p. 6-9, 1996.
CHAVARRO MESA, E. et al. The Urochloa foliar blight and collar rot pathogen Rhizoctonia solani AG-1 IA emerged in South America via a host shift from rice. Phytopathology, Saint Paul, v. 105, n. 11, p. 1475-1486, 2015.

CENTRO INTERNACIONAL DE AGRICULTURA TROPICAL (CIAT). Annual report: tropical forages program. Palmira: CIAT, 1993.

COSTA-SOUZA, E. et al. Caracterização citomorfológica, cultural, molecular e patogênica de Rhizoctonia solani Kühn associado ao arroz em Tocantins, Brasil. Summa Phytopathologica, Botucatu, v. 33, n. 2, p. 129-136, 2007.

DUARTE, M. D. L. R. et al. Etiologia da podridão do coleto de Brachiara brizantha em pastagens da Amazônia. Fitopatologia Brasileira, Brasília, DF, v. 32, n. 3, p. 261265, 2007.

GONZÁLEZ-VERA, A. D. et al. Divergence between sympatric rice- and maize-infecting populations of Rhizoctonia solani AG 1 IA from Latin America. Phytopathology, Saint Paul, v. 100, n. 2, p. 172-182, 2010.

GUTIÉRREZ, S. A. Sclerotium hydrophilum em cultivos de arroz de Argentina. Summa Phytopathologica, Botucatu, v. 33, n. 1, p. 100, 2007.

JIA, Y. et al. Rapid determination of rice cultivar responses to the sheath blight pathogen Rhizoctonia solani using micro-chamber screening method. Plant Disease, Saint Paul, v. 91, n. 5, p. 485-489, 2007.

JOHANSON, A. et al. A PCR-based method to distinguish fungi of the rice sheath-blight complex, Rhizoctonia solani, $R$. oryzae and $R$. oryzae-sativae. FEMS Microbiology Letters, Oxford, v. 162, n. 2, p. 289-294, 1998.

LANOISELET, V. M. et al. Aggregate sheath spot and sheath spot of rice. Crop Protection, Butterworth, v. 26, n. 5, p. 799-808, 2007.

LEE, F. N.; RUSH, M. C. Rice sheath blight: a major rice disease. Plant Disease, Saint Paul, v. 67, n. 7, p. 829-832, 1983.

MADARIAGA, R. et al. Rhizoctonia oryzae-sativae (Sawada) Mordue, agente causal de la pudrición o mancha agregada de la vaina del arroz (Oryza sativa L.) en Chile. Agricultura Tecnica, Chillán, v. 59, n. 2, p. 77-84, 1999.

MATSUMOTO, M. Trials of direct detection and identification of Rhizoctonia solani AG 1 and AG 2 subgroups using specifically primed PCR analysis. Mycoscience, Tokyo, v. 43, n. 2, p. 185-189, 2002.

NUNES, C. D. et al. Principais doenças do arroz irrigado e seu controle. In: GOMES, A. S.; MAGALHÃES JÚNIOR, 
A. M. (Eds.). Arroz irrigado no Sul do Brasil. Brasília, DF: Embrapa Informação Tecnológica, 2004. p. 579-633.

PABÓN GUERRERO, F. A. Pudrición de la vaina en arroz: manejo y control. Barrancabermeja: Corpoica, 1994.

SAVARY, S. et al. Rice pest constraints in tropical Asia: quantification of yield losses due to rice pests in a range of production situations. Plant Disease, Saint Paul, v. 84, n. 3, p. 357-369, 2000.

SAYLER, R. J.; YANG, Y. Detection and quantification of Rhizoctonia solani AG-1 IA, the rice sheath blight pathogen, in rice using real-time PCR. Plant Disease, Saint Paul, v. 91, n. 12, p. 1663-1668, 2007.
SNEH, B. et al. Rhizoctonia species: taxonomy, molecular biology, ecology, pathology and disease control. Dordrecht: Kluwer Academic, 1996.

TAMURA, K. et al. MEGA5: molecular evolutionary genetics analysis using maximum likelihood, evolutionary distance, and maximum parsimony methods. Molecular Biology and Evolution, Oxford, v. 28, n. 10, p. 2731-2739, 2011.

YANG, X. B. et al. Morphogenesis of microsclerotia and sasakii-type sclerotia in Rhizoctonia solani, anastomosis group 1, intraspecific groups IA and IB. Mycological Research, Manchester, v. 93, n. 4, p. 429-434, 1989. 